\title{
GROUP OR CONFERENCE RATE-MAKING AND NATIONAL TRANSPORTATION POLICY IN THE UNITED STATES
}

\author{
Daniel MarX, JR.*
}

Common carriers by rail, road, water, and air in the United States generally determine their rates, fares, classification ratings, and other charges and regulations by group consideration of these matters. Such rate-making conferences, bureaus, associations, or committees have had a long history among rail and ocean common carriers which predates their regulation by the federal government; but regulation is claimed to have stimulated, if not actually required, such group action on the part of the newer modes of transport and to have provided additional justification for cooperative action on the part of the older agencies. ${ }^{1}$ Whether the earliest conferences were designed to avoid cut-throat competition or for monopolistic exploitation need not concern us here. A contemporary valuation must be made in the context of current performance and institutions.

The controversy regarding group rate-making has been heated, and, as one writer observed, "the discussion of these differences is not carried on in a friendly atmosphere of academic debate."2 The caloric nature of the dispute may be explained by the fact that there is a great deal at stake in terms of both money and basic politicoeconomic philosophy. As in the case of martinis, tastes in political economy differ markedly; and whereas some prefer (at least for others) the stimulation of straight competition with only a dash, if any, of regulation, others prefer more regulation (especially if they can regulate themselves, or be regulated by those sympathetic to them, or are convinced that the alternatives would be disastrous). The declaration of national transportation policy contained in the Transportation Act of $1940^{3}$ does not settle the controversy, but in conjunction with the balance of the Act suggests, at least to this writer, that Congress favors a pragmatic rather than doctrinaire approach to the problem of competition and monopoly in the industry.

* A.B. 1929, Dartmouth College; Ph.D. 1946, University of California. Professor and Chairman, Department of Economics, Dartmouth College. Formerly Chief, Cargo Reports and Vessel Utilization Section, War Shipping Administration; Economic Commissioner, European Cooperation Administration; Member, Senior Staff, Council of Economic Advisers to the President. Author, Intrrnationat Shipping Cartels: A Study of Industrial Self-Regulation by Shipping Conferences (1953), and articles on overseas transportation and foreign trade. The author wishes to express his gratitude to his collcagues, Professors Martin L. Lindahl and William L. Baldwin, for their constructive suggestions.

${ }^{1}$ Board of Investigation and Research, Report on Rate-Making and Rate-Publishing Procedurcs of Railroad, Motor and Water Carriers, H.R. Doc. No. 363, 78th Cong., Ist Sess. 1-42 (1943).

${ }^{2}$ Daggett, Railroad Traffic Associations and Antitrust Legislation, 38 Am. Econ. Rev. Proc. 459 (r948).

${ }^{3} 54$ Stat. 899 , as amended, 49 U.S.C. $\$$ I (1952).

4 This does not deny the charge, especially applicable to competition between and among the various modes of transport, that the ambivalence of the promotional and the regulatory aspects of the trans- 
This paper will present a brief historical survey of group rate-making and the attendant controversy, and then discuss some salient economic characteristics and regulatory features of the different agencies of transport, with the intention of shedding some illumination on the basic problem and on some related current issues. To reduce the scope to manageable proportions, our attention will be restricted to common carriers of domestic freight by road and rail, of foreign cargo by ship, and of domestic and foreign passenger traffic by air. For the sake of brevity, group tariff-making agencies will often be referred to as "conferences," whether or not they are officially known as bureaus, associations, or by some other name.

Although it is beyond the scope of this article to describe the organization and operation of rate conferences, the details of which differ within each branch of the industry and even more among the various modes of transport, a few general comments may assist the reader unfamiliar with them. Such conferences are generally organized on a territorial or trade-route basis. They provide for the joint consideration of proposals for new rates and changes in existing rates and related matters, and are generally responsible for publishing and filing the applicable charges.

They have evolved their own rules governing the handling of proposals for rate changes, but they generally provide for proposals to be promptly docketed; and the rail and motor bureaus at least provide for hearings and notification of interested parties. Voting requirements vary from a simple majority in some conferences to unanimity in others. The right of independent action by one or more member lines is required by law for domestic rail, road, and water carriers, and is sought by the regulatory agency for air transport. ${ }^{5}$ The larger conferences often carry on their functions through various committees and are themselves apt to be linked together to provide for interterritory charges. It has been claimed that overall coordination, some allege monopoly control, is provided by the Association of American Railroads for railroads, by the American Trucking Association for road transport, and by the Air Transport Association of America for aviation. ${ }^{\circ}$ The cost of the conferences is borne by the member carriers.

portation policy of the United States makes it manifestly unreasonable to expect a regulatory agency "to administer with uniform impartiality and integrity congressional policies which are inherently contradictory and irreconcilable." Charles $L$. Dearing \& Wilfred Owen, National Transportation Polict 367 (r949). Note also Ernest W. Wilisiass, JR., The Regulation of Ratl-Motor Rate Competition $15(1958)$.

662 Stat. 472 (I948), 49 U.S.C. $\$ 5 b(6)$ (I952); I.A.T.A. Traffic Conference Resolution, 6 C.A.B. $639,645(1946)$.

${ }^{\circ}$ For a description of domestic rail, road, and water conferences, see Board of Investigation and Research, supra note $\mathrm{I}$, and Hearings Before the Senate Committee on Interstate Commerce, on S. 942, to Amend the ICC to Provide for Agreements Between Common Carriers by Railroad, etc., 78 th Cong., Ist Sess. (I943). Since I949, almost every volume of I.C.C. reports contains information concerning rate bureaus as well as the Commission's attitude concerning their practices. For air transport conferences, see Antitrust Subcomm. of the House Comm. on the Judiciary, The Airlines Industry, H.R. REP. No. 1328, 85th Cong., 2d Sess. (I958). For ocean shipping conferences, see Daniel Marx, JR., Internatronal Shipping Cartels (I953). For allegations of monopoly control, see Arne Wiprud, Justice in Transportation (I945); John G. Shott, The Railroad Monopoly (r950); Antitust Subcomm. of the House Comm. on the Judiciary, supra. 


\section{A Brief Historical Note}

The futility of destructive rate wars helped convince highly individualistic and fiercely competitive common carriers by rail and water of the advantages of cooperative action, with the result that rail freight rate bureaus and shipping conferences became increasingly common during the third quarter of the nineteenth century. ${ }^{?}$ Although the Interstate Commerce Act of 1887 prohibited pooling, which had been an integral part of early railroad rate bureau operations, the carriers felt that the cooperation necessary for compliance with the Act's proscription of prcjudicial and discriminatory rates provided added justification for group action. ${ }^{8}$

The Department of Justice, however, did not share the carriers' views and instituted an antitrust prosecution against the Trans-Missouri Freight Association. Then, as now, clear delineation of the applicability of antitrust legislation to regulated industries was lacking, but in 1897 , the Supreme Court, in a five-to-four decision held the articles of agreement governing this rate bureau to be in unlawful restraint of trade. ${ }^{\theta}$ The majority decision rejected the minority opinion that the prohibitions of the Sherman Act applied only to unreasonable restraints; ${ }^{10}$ and in the following year, the majority position was reaffirmed in United States v. Joint Traffic Association. ${ }^{11}$

Despite these decrees, railroad conferences continued to flourish and achieved their objectives with apparent legality through voluntary action and by avoiding the threat of formal sanctions. The railroads contended, and the Interstate Commerce Commission agreed, that the intricate task of rate-making would be seriously impaired without conferences. ${ }^{12}$ In I921, in response to charges of abuse, the United States Senate directed the ICC to investigate the Trans-Continental Freight Bureau. After a comprehensive investigation, the Commission reported the burcau was performing many useful functions and did not violate the Interstate Commerce Act. $^{13}$ Neither the Senate nor the Commission inquired into the status of such associations under the antitrust laws, and the Department of Justice did not press the antitrust charges for approximately forty years. ${ }^{14}$

During this period, shipping conferences were investigated by both the British and United States Governments. A majority of the Royal Commission on Shipping Rings maintained that unrestricted competition in liner shipping was impossible, that

\footnotetext{
- William Z. Ripley, Railroads-Rates and Reculation 21 el seq., 431 el seq. (ig12); Marx, op. cit. supra note 6 , at 45 et seq.

${ }^{8} 24$ Stat. 380,49 U.S.C. $\$ 5(1)$ (1952); Board of Investigation and Research, stupra note I.

${ }^{\circ}$ United States v. Trans-Missouri Freight Association, I66 U.S. 290 (1897).

${ }^{10}$ For the triumph of the "rule of reason," see Standard Oil Co. v. United States, 221 U.S. 1, 60 (1911); United States v. American Tobacco Co., 221 U.S. 106, 180 (19II).

11 $x$ II U.S. 595 (1898). 12 I2 ICC ANN. Rep. I5-16 (I898).

${ }^{18}$ In re Trans-Continental Rate Bureau, 77 I.C.C. 252 (1923).

14 It has been suggested that United States v. Trenton Potteries Co., 273 U.S. 392 (1927), and especially its reaffirmation in United States v. Socony Vacuum Oil Co., 310 U.S. I5o (1940), and Ethyl Gas Corp. v. United States, 309 U.S. 436 (I940), cast new doubt on the legality of railroad conferences. Note, Railroad Rate Bureaus and the Anti-Trust Laws, 46 Colvм. L. Rev. 990, 994-95 (1946).
} 
the stabilizing advantages of the conference were considerable, and that actual and potential competition and the countervailing power of shippers would usually check the abuses of excessive power. The minority view was that the majority both exaggerated the alleged advantages of the conference system and neglected to consider the interests of producers and consumers. Both groups, however, were willing to permit the continued existence of shipping conferences, and neither favored novel and drastic legislation. ${ }^{15}$

A committee of the United States House of Representatives (the Alexander Committee) observed that the prohibition of agreements between shipping lines to regulate competition would lead to cut-throat practices and that any large-scale disturbance of the shipping industry would be detrimental to American commerce. The Alexander Committee deplored the deferred rebate system, which had been tolerated by the British Commission, and proposed legislation to provide for government regulation of shipping. ${ }^{16}$ Most of their recommendations were incorporated in the Shipping Act of $1916 .{ }^{17}$ The validity of shipping conferences has not been seriously challenged in either of these countries since those investigations, although some practices, especially the use of the dual rate system in United States commerce, has been vigorously disputed, as we shall note in more detail subsequently. ${ }^{18}$

In 1941, the Department of Justice again became critical of railroad rate bureaus and prepared to submit indictments against them to a grand jury, but action was postponed because of the war. ${ }^{19}$ However, in mid-1944, Georgia filed suit against some twenty railroads, alleging that they had employed rate conferences to set rates which discriminated against shippers in that state. ${ }^{20}$ In the same year, the Department of Justice brought suit against the Association of American Railroads, the Western Association of Railroads, the Western Association of Railway Executives, certain bankers, and a long list of so-called "co-conspirators" which included railroads in the southern and eastern states. ${ }^{21}$ The latter complaint charged the defendants with combining in restraint of trade and with attempting to monopolize.

These challenges to the legality of railroad rate conferences produced legislation to exempt them from the antitrust laws, but only after several years, volumes of vituperation, and despite a veto by President Truman. ${ }^{22}$ The Reed-Bulwinkle Act of

${ }^{15}$ Royal Commission on Shipping Rings, Report, CMr. Nos. 4668, $4669,4670,4685$ (Igog). For a summary, see $\mathrm{M}_{\mathrm{ARX}}$, op. cit. supra note 6 , ch. 4 .

${ }^{10}$ House Comm. on the Merchant Marine and Fisheries, Report on Steamship Agreements and Affliations in the American Foreign and Domestic Trade, H.R. Doc. No. 805, 63d Cong., 2d Sess. (I9I4). For a summary see MARx, op. cit. supra note 6, ch. 4 .

${ }^{17} 39$ Stat. 728,46 U.S.C. $\$ \$ 801-42$ (1952). $\quad{ }^{18}$ Infra pt. v.

29 Daggett, supra note 2, at 455-56; Note, Railroad Rate Bureaus and the Anti-trust Lawu, 46 Colous. L. REv. $990,995-96$ (1946).

${ }^{20}$ Georgia v. Pennsylvania R.R., 324 U.S. 439 (I945).

21 United States v. Ass'n of American Railroads, 4 F.R.D. 510 (D. Neb. I945).

32 The following excerpts from President Truman's veto message contain the burden of the less strident arguments against the Reed-Bulwinkle Act: "My disapproval of this bill does not signify opposition to carrier associations as such, or to all of their present functions. Many of their activities are useful and desirable. However, this legislation is not necessary for the continuation of such activities.

"No legislation giving a major industry immunity from the antitrust laws should be enacted unless 
2948 added section 5 a to the Interstate Commerce Act and thereby explicitly relieved from the operation of the antitrust laws rate conferences for domestic common carriers if their rules, regulations, and procedures were approved by the ICC, and then only if they met the general objectives of the national transportation policy. ${ }^{23}$ The Act specifically requires that conferences recognize the right of individual carriers to take independent action in making rates if they do not wish to follow the recommendations of the bureaus and that agreements between or among carriers of different classes (modes) be limited to transportation under joint rates or over through routes.

Opponents of this legislation claimed that free competition among railroads would lead to lower rates and more efficient service and that such competition was essential to protect the public interest. They asserted that traffic conferences restrained competition and that ICC regulations were not and could not be counted on to protect the public when competition is removed. Supporters of section $5^{\text {a argued }}$ that these conferences did not restrain competition, that a sanctioned plan for them has technical advantages, and that ICC regulation is entirely adequate to safeguard the public interest. ${ }^{24}$

Conference rate-making by road and airline common carriers is historically more directly associated with the introduction of regulatory legislation than it was for rail carriers and shipping lines. Such arrangements might have evolved in air transport without regulation for reasons similar to those that prevailed in the rail and shipping industries, but the fragmentation of the motor-carrier industry into numerous units, many of them small, might have prevented such cooperation. The role of conferences in the aviation industry has recently been examined and criticized by a subcommittee of the House of Representatives. ${ }^{25}$

adequate alternative safeguards are provided for the public interest. This measure fails to provide such safeguards. ...

"Even though transportation rates are subject to regulation by the Interstate Commerce Commission, the public interest nevertheless demands that the general national policy of maintaining compctition continue to be applied to this industry." 94 Cong. Rec. 8524 (1948).

${ }^{23} 62$ Stat. 472,49 U.S.C. $\$ 5$ b (1952). Neither the Reed-Bulwinkle Act nor the Interstate Commerce Act applies to carriers by air. Air transport is covered by the Civil Aeronautics Act, $\$ 4$ r2 of which permits conference rate-making. 52 Stat. 1004 (1938), 49 U.S.C. $\$ 492$ (I952); of. 72 Stat. 770,49 U.S.C.A. $\$ 1382$ (Supp. 1958). Shipping in United States foreign trade is subject to the Shipping Act of I916, $\$ 15$ of which permits rate conferences. 39 Stat. 733,46 U.S.C. $\$ 81_{4}$ (1952).

${ }^{21}$ For vigorous statements of views in opposition to the Reed-Bulwinkle Act, sce WIprud, op. cit. supra note 6; ShotT, op. cit. supra note 6. For a defense of the Act, see Charles D. Drayton, Transportation UNDER Two Masters (1946). These three works draw heavily on testimony presented at congressional hearings. Of special interest are the views of the Department of Justice in opposition to the legislation, and of the ICC and Coordinator of Transportation in support. It is not without sig* nificance that shippers generally testified in favor of rate conferences. This is probably attributable to their greater interest in rate stability than in the rate level. Stable rates help shippers in calculating costs to set contract prices, facilitate forward trading, and remove the danger that competitors will obtain the advantage of lower rates on later shipments. See House Comm. on the Merchant Marine and Fisheries, supra note 16; Hearings Before the Senate Committee on Interstate Commerce on S. 942, to Amend the ICC to Provide for Agreements Between Common Carriers by Railroad, etc., 78th Cong., Ist Sess. (1943).

${ }^{25}$ The activities of Air Transport Association of America in curbing domestic competition and the cartel activities of the International Air Transport Associaition (IATA) are commented on. Antitrust Subcomm. of the House Comm. on the Judiciary, supra note 6. 


\section{II}

\section{Some Salient Economic Characteristics}

Common carriers by rail, water, and air have several economic characteristics in common, although in varying degree. Each of these characteristics by itself is not unique to transport, but the combination helps to explain the prevalence of conference rate-making in the transportation industries. First, as common carriers, they have a public utility status. Secondly, because of either internal economies of scale, external economies of scale, joint costs, unused capacity, or some combination of these, sizable elements of cost, known as supplementary costs, cannot be identified with any particular traffic movement and, consequently, must be arbitrarily allocated. ${ }^{20}$ Of these, unused capacity on one, several, or all legs of a round-trip is usually the strongest cause of sizable supplementary costs per unit of service. ${ }^{27}$ Thirdly, they sell their product-transportation service-to disparate groups of buyers, most of whom are knowledgable professionals, with widely varying elasticities of demand. ${ }^{28}$ The professionalism of buyers of transport service, however, does not assure that the benefits of lower freight charges will always be shared with either consumers or suppliers. The incidence of freight rates, like that of taxes, depends on the degree of competition and elasticities of demand and supply in the product and factor markets. It is not without significance that shippers are often more interested in the stability of rates, and the elimination of discrimination unless it favors them, than they are in the rate level. Of course, if the rate level impedes the volume of traffic, shippers are concerned; but so are the carriers, unless they believe it is more remunerative to carry a smaller volume at the higher rate.

${ }^{20}$ In the case of railroads, expensive roadbeds and depots contribute initially to high fixed (supplementary) costs, although over a long period, many of these expenses become variable and the relative importance of variable costs tends to rise as traffic density increases. Since traffic density is, in part, dependent on rates, an element of indeterminacy emerges if rates are, in turn, based on costs. Shipping and airlines, like railroads, have certain overhead management costs; but unlike the rails, they have no investment in expensive rights of way and generally they do not own their own terminals. High supplementary costs are attributable to large fixed investment in expensive and large units of transport, and though these units, unlike a railroad's right of way, can be transferred from one route to another, the commitment to a previously advertised schedule and the dependence of goodwill on regular and frequent service often causes a ship or plane to depart with unused capacity.

${ }^{37}$ True joint costs are most apt to arise in transportation when a service is fully utilized in one direction but not in the opposite direction. In short, there is unused capacity in one direction, and, consequently, this may be considered, for present purposes, a limited case of unused capacity.

28 The demand for the various modes of common-carrier transport is not only affected by the large variety of goods to be moved, but is also importantly influenced by the substitutability of other transportation as well as by the competition of alternate markets and routings. In addition to intracarrier competition, which is experienced by all forms of common carriage-except in those instances where no feasible alternative exists-there is often considerable price competition between the different modes of transport. Railroads are subject, in varying degree, to competition from all other forms of transporte.g., ships and barges, pipelines, planes, and trucks, whether common, contract, or private carriers. Cargo liners may be confronted with tramp and nonconference berth competition. Passenger airlines often compete with passenger vessels and chartered planes. The extent and intensity of such competition, which varies from route to route and from commodity to commodity, must be borne in mind, along with the degree and efficacy of regulation to which it is subject, in an evaluation of the monopoly power of each rate-making conference. 
The second characteristic-arbitrarily allocable costs-leads in many cases to cutthroat pricing. When the ratio of supplementary costs to variable costs is high and an expansion of operations, which will permit a firm's fixed plant to be used more efficiently, is possible, then a situation conducive to cut-throat competition is present. Cut-throat pricing may lead to a suitable reduction of the excess capacity, but when resources are long-lived and not very mobile, it is more apt to lead to outright cooperation in restraint of trade or to a live-and-let-live policy under price leadership. Under each alternative, price competition is submerged and a monopolistic type of situation arises. The monopolistic character of the latter two alternatives, and the attendant ability to impose a level of rates that may produce monopoly profits, is obvious, although the price leadership variety may be less permanent and is apt to be less exploitative than formal cooperation without adequate regulation.

The elimination of excess capacity, however, would not usually be a sufficient condition to assure workable competition, because with or without excess capacity, the number of independent concerns would rarely be large enough. The inevitable result is a monopoloid situation which, in the case of multiple-product firms or firms confronted with some demands relatively more inelastic than others, will lead to price discrimination, if it did not already exist in some degree. ${ }^{20}$ This means that some buyers pay more than their proportionate share of arbitrarily allocable costs, whereas others pay less. Taken by itself, this may or may not be economically sound, the result depending on the operation of the venture as a whole. For example, any shipment that pays more than its prime (out-of-pocket) costs makes a contribution to the venture. Whether other shipments should pay more than the sum of their prime costs plus their proportionate share of supplementary costs depends on whether there is excess and relatively immobile capacity and on whether the unused capacity is chronic, or of a seasonal or cyclical type, or due to anticipated growth. If chronic, the replacement of all the facilities need not be provided for, and

\footnotetext{
${ }^{29}$ Price discrimination, as noted below, is apt to be the rule rather than the exception in industrial pricing. The distinctive features of transport are its public-utility character and the difficulty of reaching general agreement on whether price discrimination is associated with multiproduct production and the ease of separating markets, as it clearly is in the case of passengers and goods transport, or only with the carrier's ability to separate the product (service), as when different rates are charged for transporting similar, but not identical, products between the same two points.

Professor Clemens demonstrates "that price discrimination and multiple product production are not exceptions to general practice, but are rather the essence of customary action. The distinction betwcen a producer selling a single product at different prices and one selling different products in varying markets at differing percentages of profit is a distinction of degree only. What a firm has to sell is not a product, but rather its capacity to produce. Insofar as firms are motivated by the marginal principle, there is a tendency to push production towards the point where marginal cost is equal to demand price for the least profitable unit produced. In this manner 'capacity' operation is achicved. The limits to the process are institutional rather than theoretical. Under conditions of monopolistic competition this probably results in a situation where only normal profits are obtained. Whatever the amount of profit, it is obtained only by constant manipulation of the price and product line. The theory of price-discrimination must be viewed as the heart of price-cost theory rather than a peripheral case. The firm that does not discriminate in its pricing policy, or differentiate in its product line, or invade new markets, dies in the competitive struggle-and business management does not commit suicide." " Eli W. Clemens, Price Discrimination and the Multiple Product Firm, in AMERtcan Economic Ass's, Respings in Industrinz Organization and Public Polici 262, 276 (1958).
} 
rates in excess of prime and proportionate supplementary costs are not justified; but in the other instances of excess capacity, they may be justifiable. Appropriate policy, consequently, will depend on the circumstances.

As long as such price discrimination means "cheap" rates for such different commodities as iron ore or wheat and "dear" rates for television sets, ladies millinery, or jewelry, there may be no great harm in some discrimination against television sets and in favor of coal. But if the discrimination is against one coal shipper because he does not have the choice of water or rail transport, or against a television shipper who does not have a road or rail option, and in favor of coal and television shippers, respectively, who are not limited to one means of transport, then the public-utility characteristic cries out against such treatment and regulation has generally been favored. Whether or not regulation in this country is and can be adequate to protect the public against undue discrimination and against the exploitative power of monopoloid situations without the application of antitrust legislation to the transport industries remains a matter of controversy, as does the proper role of competition between the various modes of transport.

Common motor carriers have been omitted from the foregoing analysis for two reasons. First, their supplementary costs are relatively small in consequence of the smallness of the units of transport and because they use public thoroughfares. Secondly, and because of the same characteristics, actual and potential competition from private and contract carriers as well as from other common carriers is greater, and effectively limits the ability to discriminate. Competition in trucking can reasonably be expected to produce workable results within the trucking industry on routes of sufficiently heavy traffic. ${ }^{30}$ Cut-throat competition, when it has occurred, has generally been attributed to the fragmentation of the industry and the willingness of many small truckers to operate below their full costs, and the folly of newcomers willing to replace those who failed. ${ }^{31}$ (However, in trucking, as in all forms of transport, it may be remunerative to haul freight at less than fully allocated costs in one direction in those joint-cost situations when the volume of traffic outbound and inbound is not well-balanced.) It is not astonishing, therefore, that group ratemaking among motor carriers has developed largely in conjunction with the uniformity required by regulation. Before returning to a consideration of rail transport, it should be noted that lawful rate discrimination practiced by railroads enabled un-

\footnotetext{
${ }^{\infty}$ Some economists have concluded that the cost characteristics of air and water transport, with their use of free rights of way and the mobility of their craft, resemble motor rather than rail transport, and that regulation of entry and even of rates for them, predicated on lumpiness over large stretches of their cost functions, is based on a false analogy. Most recognize, however, the public-utility aspect of common carriers by air and water and the importance to the public of regular and frequent service. Whether or not an uncontrolled entry will result in undesirable irregularity of service or in cut-throat pricing remains in dispute. Compare Lucile Sheppard Keyes, Federal Contror of Entry into Air Transportation 91-97 (i95I); Claude E. Puffer, Air Transportation ch. 2, at 246-55 (I941); Dewcy, The Transportation Act of 1940, 3 I AM. Econ. Rev. 15, 18-21 (1941); Nelson, New Concepts in Transportation Regulation, in' National Resodrces Pinaning Board, Transportation and Nationat Policy 197 (1942); with D. Philip Lockin, Economics of Transportation 779-80, 857-59 (1954).

'Locklin, op. cit. supra note 30, at 701-02, 738-39; WilliaMs, op. cit. supra note 4, at 225-26.
} 
regulated motor carriers to go after the higher-rated commodities and leave the lower-paying goods to the rails. This "skimming of the cream" off the railroads' traffic mix does not necessarily lead to the establishment of a transportation system based on the inherent economic advantages of each mode, as stipulated by the declaration of policy in the Transportation Act of 1940.

Conference rate-making, therefore, appears to have been stimulated by the instinct of self-preservation in the rail, water, and air transport industries, which is not to deny that baser motives may also have been at work. Group action has also been necessary to establish joint rates and through routes between connecting carriers. Simplification and uniformity of commodity classification and of shipping rules and regulations are other fruits of carrier cooperation and have generally been in the public interest. These latter functions of group action have at times been attacked as unreasonably discriminatory or in unreasonable restraint of trade, but such complaints can, for the purpose of this article, be subsumed under its consideration of conference rate-making. The extent to which self-preservation justifies group rate activity can be best understood in the context of regulation applicable to the various modes of transport.

\section{III}

\section{Some Salient Regulatory Features}

The regulatory features most germane to this article are mainly those statutes relating to rates, entries, abandonments, and to the supervision of conference agreements. The efficacy with which these provisions are administered is also of relevance, but such an evaluation would enlarge this review well beyond the available limits of time and space.

Since 1940 , all common carriers by rail, road, and water between interstate mainland United States points have been under the jurisdiction of the ICC, which has the authority to set maximum, minimum, or actual rates for common carriers and minimum rates for contract carriers. ${ }^{32}$ A roughly similar "rule of rate-making" that recognizes the public interest in adequate, efficient transportation at the lowest cost consistent with the furnishing of such service by each form is applicable to all modes of transport. $^{33}$ Consequently, the ICC has the authority to prevent undue discrimination, to moderate rate competition within and between the various modes of surface transport, and to prevent an unreasonably high level of rates when the remaining elements of competition are not adequate. Commission approval is re-

\footnotetext{
32 The Motor Carrier Act of 1935 , enacted as pt. II of the Interstate Commerce Act, extended federal economic regulation to the trucking industry. 49 Stat. 543,49 U.S.C. $\$ \$ 301-27$ (1952). The Transportation Act of 1940, among other things, attempted to define a national transportation policy; and as pt. III of the Interstate Commerce Act, it transferred the regulation of interstate water carriers from the Maritime Commission to the ICC and expanded control over such carriers. 54 Stat. 929, 49 U.S.C. $\$ \$ 901-23$ (1952).

3s Stat. 912 (1940), 49 U.S.C. $\$ 15 a$ (I952); 54 Stat. 924 (1940), 49 U.S.C. $\$ 316$ (i) (1952); 54 Stat. 937 (I940), 49 U.S.C. $\$ 907$ (f) (1952); 52 Stat. Iorg (1938), 49 U.S.C. $\$ 642$ (c) (1952). The clauses applicable to motor and air carriers also stipulate that the inherent advantages of these forms of transport be considered.
} 
quired for consolidations and unifications of common and contract surface carriers. Furthermore, the ICC has control of entrance through the requirement of certificates of public convenience and necessity for common carriers and permits for contract carriers; and for railroads only, the Commission has control over abandonments. However, the exemption from economic regulation of private road and water carriers, of motor carriers carrying agricultural products, of bulk carriers by water, and the limited authority over contract road and water transport not only limits the ability of the ICC to control domestic surface transport, but also modifies the need for regulation by allowing for a substantial element of actual or potential competition from unregulated or partially regulated transportation. The Civil Aeronautics Board has similar authority, including the power to prohibit abandonment, over common carrier air transport within the United States. ${ }^{34}$ Contract carriers by air are not regulated, and the $\mathrm{CAB}$ is empowered to exempt carriers from regulation.

In the nation's foreign trade, the Federal Maritime Board and the CAB have the responsibility of regulating shipping and aviation, respectively, but neither is authorized by specific regulation to establish minimum or maximum rates. ${ }^{35}$ The FMB has no statutory control over entrances and abandonments, but the CAB is authorized to require American flag planes to obtain certificates, and foreign-flag planes to obtain permits, in order to engage in the foreign air transportation of the United States. $^{36}$ Holders of certificates may not abandon a service without the CAB's sanction. Treaties of friendship, commerce, and navigation grant the shipping of almost all nations of the Free World unlimited access to American ports, but the bilateral agreements that cover commercial air transport provide for negotiated control over the volume of such traffic. ${ }^{37}$

As previously indicated, shipping conferences were brought under regulation by section fifteen of the Shipping Act of $1916 .^{38}$ A similar pattern was followed under section 412 of the Civil Aeronautics Act of $193^{33^{39}}$ The Reed-Bulwinkle Act of 1948 , by adding section 5 a to the Interstate Commerce Act, provided for ICC regulation of conferences formed by domestic common carriers by rail, road, or water. ${ }^{40} \mathrm{Sec}-$ tion fifteen requires that all agreements, understandings, conferences, or other arrangements between parties subject to the Shipping Act which affect competition in any way must be filed with the FMB. The Board may disapprove, cancel, or modify any such agreement or modification thereof deemed to operate to the detriment of United States commerce, to be in violation of the Act, or to be "unjustly

3652 Stat. 987 (1938), 49 U.S.C. $\$ \$ 48 \mathrm{r}-96$ (1952).

35 Only through their ability to withdraw the approval which exempts conference agreements from antitrust legislation can the FMB and $\mathrm{CAB}$ attempt to control unreasonably high rates. For shipping, see Marx, op. cit. supra note 6, at Ir4-I5; for aviation see Bebchick, The International Air Transport Association and the Civil Aeronautics Board, 25 J. AIR L. \& CoM. 8, II-I2 (1958).

${ }^{36}$ All matters decided by the $\mathrm{CAB}$ relative to such certificates and permits are required to be submitted to the President for approval. 52 Stat. Ior 4 (I938), 49 U.S.C. $\$ 60$ (1952).

${ }^{37}$ Jown C. COOPER, The RIGHr to FLY I27-28 (I947); Sorenson, Law of the Sea, 520 INT'r ConcininrION I95 (1958); Antitrust Subcomm. of the House Comm. on the Judiciary, supra note 6, at 33-34.

${ }^{38} 39$ Stat. 733, 46 U.S.C. $\$ 81_{4}$ (1952).

${ }^{39} 52$ Stat. I004, 49 U.S.C. $\$ 492$ (1952).

${ }^{10} \mathrm{Cf}$. note 23 supra. 
discriminatory or unfair" between carriers, shippers, exporters, importers, or ports, or between exporters from the United States and their foreign competitors. Approved agreements are exempted from the antitrust laws. Sections $4^{\mathrm{r} 2}$-14 of the Civil Aeronautics Act of 1938 similarly provide exemption from antitrust legislation to air carriers when their agreements have been approved by the $\mathrm{CAB} ;{ }^{41}$ and, as previously indicated, section 5 a provides analogous relief for domestic surface transportation when the ICC has approved the agreement.

\section{IV}

\section{Some General Observations}

What are the evils attributed to conferences? They are essentially the evils of monopoly-that excessive profits are earned by charging a higher price than that which would prevail under pure competition through the monopolistic ability to restrict the volume of service below the competitive norm. Furthermore, price discrimination is made possible; but since some price discrimination can be in the public interest and unreasonable discrimination by common carrier is subject to effective regulation, criticism on this count is muted. Rate regulation, however, is less effective in preventing a level of rates that is too high. Actual and potential intra and intercarrier competition can squeeze out monopoly profits by reducing the level of rates toward the competitive norm. In addition to gearing rates to the costs of the most efficient operator, competition may also stimulate useful innovations and hasten the elimination of excess capacity. ${ }^{42}$

But just the right amount of competition cannot be counted on. The competition may, unless regulated, become cut-throat, and the level of rates reduced below the competitive norm until a few survivors decide to live-and-let-live. Or the competition may be held in check by adoption of a live-and-let-live oligopoly policy to begin with, and rates may be retained above the competitive norm. Such oligopolistic solutions may eliminate remaining monopoly profits by attracting excess carrying capacity. The results will depend importantly on the ease of entry and withdrawal and on the transport policies of governments.

Does the conference system resemble more closely the monopoly with its excess profits achieved by curtailing output to keep prices high, or does it resemble more nearly the oligopoly with its rates above the competitive norm but probably below the monopoly level? The answer will depend largely on: (I) the right of conference members to act independently and their propensity to do so; (2) the ease of

$\$ 2$ Stat. 1004,49 U.S.C. $\$ \$ 492,494$ (1952). Unapproved agreements are made expressly illegal by $\S 15$; but $\$ 4^{12}$ contains no such provision. The FMB may approve, disapprove, or modify an agrecment; while the $\mathrm{CAB}$ may only approve or disapprove. For other interesting differences between $\$$ is and $\$ 4 \mathrm{I} 2$, see Kharasch, Conferences of Carriers by Sea: Freedom of Rate Fixing, $23 \mathrm{~J}$. AmR L. \& CoM. 287,292 (1956).

${ }^{3}$ E.g., it has been argued, that fare competition from nonscheduled carriers was necessary to establish low-fare aircoach service in the United States and that new traffic from an untapped market was thus developed. Antitrust Subcomm. of the Housc Comm. on the Judiciary, supra note 6, at 87.94. 
entry; and (3) the actual and potential competition from other carriers and market areas.

We have seen that the right of independent action is provided common carriers in the domestic services and has been sought by the $\mathrm{CAB}$ for international airlines. The propensity to act independently, however, cannot be provided by regulation, but protection against retaliation can be. Ease of entry depends on initial costs and the difficulties of obtaining certificates or permits when they are required. The cost of entry is highest for railroads and least for motor carriers. Except for international shipping, the regulatory agencies have some control over entries. Competition from private and contract carriers is either unregulated or partially regulated; and competition from other market areas may or may not be regulated. Competition between different modes of domestic transport is subject to regulation, but proper coordination has proven difficult.

In short, the choice is not between a conference monopoly and pure competition, but generally is between a conference oligopoly and ordinary oligopoly. In any evaluation, the benefits as well as the evils attributed to conferences should be kept in mind. Since the evils have just been reviewed, it may be appropriate to recall that the claimed benefits include the avoidance of cut-throat rate wars, rate stability, and uniformity of shipping regulations and practices. Similar advantages are attributed to some ordinary oligopolies. A general rule for making a choice is not available. In view of the difficulty of choosing between an ordinary oligopoly and a conference oligopoly, it should not be astonishing that in the case of industries with a prominent public-utility aspect, the dilemma has often been resolved by providing for the regulation of a conference oligopoly. The problem of obtaining the benefits of regulated cooperation without losing the advantages of competition thus emerges as the real problem.

We have seen that transportation rate conferences generally were formed in response either to cut-throat competition or to the uniformity required by regulatory legislation. Even in the trucking industry, where the economic characteristics are the most conducive to workable competition, "uncontrolled competition ... s showed" no tendency to reach an equilibrium at a level where marginal and average costs. became equal"; so that "effective rate bureaus ... have, with the aid of the [ICC] in response to their requests, become the most important stabilizing influence in the industry." 43 It is not clear why the competition within and among the transport industries has been more aggressive and less prone to develop a live-and-let-live policy like that which characterizes many other United States industries where fewness of sellers and large supplementary costs are common. There are some indications that such a development may be occurring, but it is too early to count on it underall types of economic weather, lest, as Santayana has warned, we are among those who, having failed to remember the past, will be condemned to repeat it.

${ }^{t 0}$ WirlinMs, op. cit. supra note 4 , at 225-26. 
Although conferences can doubtlessly be very helpful in achieving rate stability, they are not necessary for this function if the regulatory agency has, as the ICC and $C A B$ do for domestic transport, specific rate powers and is willing to use them. Greater use of specific rate authority, however, is contrary to much recent thinking concerning transportation; and the wind seems to be blowing in the direction of greater competition and less infringement on traditional managerial responsibilities by regulatory agencies. ${ }^{44}$

The major question for both domestic and foreign transport, is whether conferences on balance are more harmful to the public interest than they are helpful. The answer will depend largely on one's attitudes towards the efficacy of regulation and the prospect for workable competition if conferences are abolished.

Several students of the effectiveness of the regulatory process have expressed the opinion that a specialized, independent agency, whose function is the daily supervision of a particular segment of the nation's industry, inevitably tends to become imbued with the special viewpoint of the regulated industry, to the possible exclusion or undue subordination of the public interest.5 Despite this criticism, which is mainly applicable to the general level of rates and to competition between different modes of transport, there has been little complaint regarding the effectiveness of the ICC, $\mathrm{CAB}$, and FMB in checking unreasonable discrimination. ${ }^{4 \mathrm{~b}}$

Whether a better level of rates and whether a more economical allocation of traffic among the various agencies of transport would be achieved by more competi-

"Dearing \& Owen, op. cit. supta note 4, at 37I-75; Presidential Advisory Comm. on Transport Policy and Organization, Revision of Federal Transportation Policy 8-14 (I955). It should also be noted that in the latter part of 1955 , the $\mathrm{CAB}$ authorized competition in a number of major traffic markets that were formerly monopoly routes. Antitrust Subcomm. of the House Comm. on the Judiciary, stipra note 6 , at $20-21$.

Two interesting studies of United States domestic transportation have recently appeared: Joun $\mathbf{R}$. Meyer, Merton J. Peck, John Stenason, \& Charles Zwick, The Economics op Competition in the Transportation Industries (1959), and James C. Nelson, Railroad Transportation and Pudlic Policy (r959). Meyer et al. favor heavy reliance on the forces of market competition, a substantial reduction in regulation, and the abolition of rate bureaus. These policy recommendations are made after the authors have considered statistical cost studies of their own design for railroads, accounting cost studies of other modes of transport, and the market structure of the domestic transport industries. Their study concedes, at pp. $27 x, 272$, that "reform is most urgently needed, however, not in public policy but in the thinking of managerial and union groups involved in the transportation industry," and that "inculcating necessary new attitudes into the thinking of managerial groups will probably be the most important single difficulty barring the achievement of the rationalized transportation system outlined here." The writer's far more tolerant attitude towards rate conferences is predicated in part on the belief that greater refinements in cost accounting than were employed by Meyer et al. will indicate a larger role for value of service rate-making than they admit, and in part by the conviction that "leopards" change their spots slowly, if at all.

Nelson also stresses the need for greater competitiveness on the part of the railroads, but he makes no explicit recommendation for rate bureaus. It may be inferred that his attitude toward them is unfavorable. See pp. 188, 349-50. But cf. pp. 370-7x. The workable competition among the various modes of domestic transport advocated by Nelson might conceivably be accelerated by the abolition of rate conferences, but a careful reading of his volume can also lead one to conclude that they will remain a helpful adjunct of interagency competition for the foresecable future.

"E.g., Huntington, The Marasmus of the 1.C.C.: The Commission, the Railroads, and the Public Interest, 61 YALE L. J. 467 (1952); Jaffe, The Effective Limits of the Administrative Process: A Reevaluation, 67 HARv. L. REv. 1105 (1954).

${ }^{4}$ Cf. Dearing \& OWen, op. cit. supra note 4 , at 365-68. 
tion remains to be seen. Cut-throat competition was the result in the past and may again be the result in the future. On the other hand, a relatively stable oligopolistic solution, similar to that in many other industries, cannot be ruled out. But it is difficult to see where this would differ greatly from the existing conference arrangements, unless one believes the regulatory agency is unable to assure approximately as much independence of action as would exist under an ordinary oligopoly.

It can be argued that regulation currently is unable to protect the public interest adequately and that, therefore, more intercarrier competition is necessary. While such an increase in competition might be in the public interest, there is no guaranty that recent developments have changed the character of the industry sufficiently to assure an improved result. Yet, in either event, with or without more competition, it does not follow that the abolition of regulated rate conferences is necessary for more socially beneficial intercarrier competition.

The situation in the foreign carrying trades differs in some respects from that in domestic transport, although the general conclusions are similar. The FMB has no regulatory control over entrances and abandonments, except indirectly in so far as subsidized American-flag operations are concerned; and although the $\mathrm{CAB}$ has some jurisdiction over the volume of service, its powers are attenuated by the requirements of international comity. In addition, the FMB has insisted since $194^{\circ}$ that conference membership be open to all common carriers evidencing the intention and ability to operate a regular service. ${ }^{47}$ Neither the FMB nor CAB have direct control over the level of rates, although both have, in a sense, "usurped" such power through their ability to threaten to disapprove conference agreements. ${ }^{48}$ Such threats have been employed sparingly, perhaps because the alternative of open rates would be as unwelcome as the proposed change, and perhaps because of the difficulties inherent in proscribing rates in international trade, where conflicting jurisdictions could lead to an impasse. Finally, except for active competition for passengers on some routes, the degree of competition from other modes of transport does not appear as great as it does domestically for both passengers and most commodities.

Once again, we come to the conclusion that although the result under conferences is probably not optimal, the likely alternatives promise no better. As in the case of domestic transport, the alternatives are cut-throat competition or a live-andlet-live oligopoly. It can be argued that the far weaker regulatory powers over foreign transport require a greater element of competition to protect the public interest. But there is no certainty that an oligopolistic arrangement without the conference structure will provide the public with greater protection. Furthermore, the international character of the business and the involvement of governments in much shipping and in almost all airlines recommend the conference method as a

\footnotetext{
${ }^{17} \mathrm{MARx}$, op. cit. supra note 6, at I22-25; American Hawaiian S.S. Co. v. Intercontinental Marine Lines, 4 F.M.B. I60 (r953); Agreement and Practices Pertaining to Limitation on Membership-Pacific Coast European Conference, 5 F.M.B. 247 (1957).

${ }^{8}$ E.g., for shipping, see Weil v. Italian Line, I U.S.S.B.B. 395, 398 (1935); for aviation, Pan American World Airways et al., Re Rate Matters and Traffic Matters, I8 C.A.B. 648 (I954).
} 
useful means of compromising international differences one step removed from the governments themselves.

It may be concluded, therefore, that conferences can neither be given a completely clean bill of health, nor be condemned out of hand. The situation for each mode of transport differs, as do the conditions on different routes. The elements of actual and potential carrier and commodity competition, cost data, the ease or difficulty of entry and withdrawal, and the efficacy of regulation are among the important variables that must be appraised. In international transport, international relations must also be among the criteria. Each sector of the transport industries must be examined and evaluated in the light of its economic characteristics and of prevailing and feasible regulatory controls. And careful estimates must be made of the probable alternatives, as distinct from the optimal results promised by textbook models of competition. The benchmarks that are employed must be measured against reasonably well-defined national and international transportation policies in which strategic as well as economic considerations are incorporated. To the writer, this suggests the need for clear statements of our nation's domestic and foreign transport policies, and then for a circumstantial approach to such elements of the problem as the role of conference rate-making. A doctrinaire solution of problems with so many variables and indeterminacies would be hazardous. In the following section a discussion of a currently controversial conference practice, the dual-rate system, will provide an illustration of the circumstantial approach.

V

\section{An Example of the Circumstantial Appronch: The Dual-Rate or Exclusive-Patronage Contract System}

The circumstantial approach, whereby an attempt is made to base regulations on particular circumstances, is illustrated by recent developments regarding the legality of a tying arrangement known as the dual-rate or exclusive-patronage contract system that is practiced by the majority of shipping conferences. ${ }^{40}$ The legality and economic necessity of shipping conferences has not been directly challenged, but their practice of charging shippers who do not sign an exclusive-patronage contract a higher rate for a given commodity carried on a given route than is charged

${ }^{40}$ In March 1959, there were, according to the Department of Justice, I13 shipping conferences in the foreign trades of the United States, sixty-three of which employed the dual-rate system. N. Y. Times, March 12, 1959, p. 59, col. 6 . The terms of these contracts vary for different conferences, depending on the particular requirements of the trade. The contract employed by the North Atlantic Continental Freight Conference, approved by the FMB in January 1954 , is fairly representative. It provided that signatory shippers will forward by vessels of conference carriers all commodities, exccpt bulk cargoes and a few specified commodities, that they may ship from United States North Atlantic ports to a specificd range of northern European ports, unless conference carriers are unable to reserve space within three days after application by the shipper on a vessel sailing within fifteen days of the desired time. In return, the conference carriers agree to charge signatories a rate $10 \%$ below the rate applicable to nonsigners. The conference carriers agree not to increase contract rates in any contract period, except in accordance with certain notice provisions, to transport all commodities tendered by signatories that can be accommodated, and to maintain adequate service. The contract runs for successive six-month periods, unless either party gives sixty days prior notice of termination. 
those who do sign such an agreement has been hotly contested. The attack has been spearheaded by the Isbrandtsen Company and has been supported by the Departments of Justice and Agriculture. The FMB has defended the practice, but as a result of court action, has sharpened its scrutiny of the terms of these contracts. Especial attention has been given to the need for such contracts and to whether the differential between contract and noncontract rates is arbitrary and unreasonable. ${ }^{50}$

The legality of the practice ultimately revolved around the intent of the Congress in drafting section fourteen of the Shipping Act of 1916 , whether or not the dualrate contract constitutes "retaliation," and the doctrine of "primary jurisdiction." "51 The majority of the Supreme Court pointed out that section fourteen, First, outlawed deferred rebates, 52 and section fourteen, Third, outlawed "resort to other discriminating or unfair methods," without qualification as to whether these methods were "unjustly discriminatory or unfair," as is the case in section fourteen, Fourth, and elsewhere in the Act. ${ }^{53}$ The majority opinion of the Supreme Court, therefore, held that a dual-rate contract to stifle outside competition is unlawful..$^{54}$ Since it is difficult to distinguish between an offensive tactic and a defensive ploy, the shadow

${ }^{50}$ Isbrandtsen Co., Inc., a prominent nonconference steamship operator, brought suit in 1948 to enjoin zwo conferences in the North Atlantic trade from using dual-rate contracts. The litigation moved back and forth between the FMB and the courts, and although the district court declined to rule on the validity of the dual-rate system, a permanent injunction was granted against the use of the contracts on the grounds that the differential between contract and nonicontract rates was arbitrarily determined and unreasonable. Isbrandtsen Co. v. United States, 96 F. Supp. 883 (S.D.N.Y. I95I). This decision was affirmed without opinion by the United States Supreme Court by an equally divided vote. A/S J. Ludwig Mowinckles Rederi v. Isbrandtsen Co., 342 U.S. 950 (1952). For a description and analysis of the legal developments in this series of litigation, see Sisk, Federal Maritine Board Procedure and the Legality of Dual Rate Shipping Contracts, 64 YALE L. J. 569 (1955); Sheehan, Exclusive Patronage Contracts in International Air Transportation, 21 J. Air L. \& Cox. 159 (I954).

This decision was followed by more careful FMB scrutiny of dual-rate contracts on other routes, several of which were also directly challenged by the Isbrandtsen Co. An important series of litigation involved the Trans-Pacific Freight Conference of Japan, 4 F.M.B. 744 (I955); and another series, the Japan/Atlantic and Gulf Freight Conference, 4 F.M.B. 706 (1955). This latter series was finally resolved by the United States Supreme Court in a 6-to-3 decision which held the dual-rate contract in the latter case unlawful. FMB v. Isbrandtsen Co., 356 U.S. 48I (1958). All of the relevant Isbrandtsen litigation is summarized in The American Shipping Industry and the Conference System, II STIx. L. REv. I;6, 144-48 (1958).

${ }^{61}$ FMB v. Isbrandtsen Co., 356 U.S. 481 (1958). For $\$ 14$, see 39 Stat. 733, 46 U.S.C. § 812 (I952). For additional comments on "primary jurisdiction," see Staff of SuBcom. No. 5, House Comm. oN tHE Judiciarx, 84th Cong., 20 Sess., Judicial Doctrine of Primary Jurisdiction as Applied in Aintitrust Surrs (Comm. Print 1957).

"s The deferred rcbate provides that a shipper who, during a specified period of time, fails to contine his shipments exclusively to conference carriers, loses his right to the rebate not only for goods shipped during the specified period, but on goods shipped during the previous period as well.

${ }^{6}$ FMB v. Isbrandtsen Co., 356 U.S. $48 \mathrm{I}$ (1958). For other sections of the Act modifying discriminatory rates or practices by such words as unfair, unjust, or unreasonable, see $\$ \$ 15,16$ and 17,39 Stat. 733-34, 46 U.S.C. $\$ \$ 814,815$, and 816 (1952).

Es FMB v. Isbrandtsen Co., 356 U.S. $48 \mathrm{x}$ (1958). The proposed dual-rate contract had been approved by the Japanese Fair Trade Commission, whose requirements were that: ( $I$ ) the differential should not exceed $9.5 \%$; (2) f.o.b. buyers should be free to designate the vessel to carry their goods, and the contract signer should be free to follow the buyer's designation without penalty; (3) liquidated damages may be $50 \%$ of the amount of the contract rates which the shipper would have paid on conference vessels; and (4) the contract should be terminable, on three months' notice. Contract RatesTranis-Pacific Freight Conference of Japan, 4 F.M.B. 744 (1955); Contract Rates-Japan/Atlantic and Gulf Freight Conference, 4 F.M.B. 706 (1955). 
of doubt was cast over the legality of all dual-rate contracts in United States foreign trades. ${ }^{55}$ The minority, in upholding the legality of the practice, disagreed with the majority's interpretation of congressional intent and stressed the doctrine of "primary jurisdiction" as a means of achieving the proper distribution of the lawenforcing roles between administrative agencies and courts in the discharge of functions for which courts have neither training, experience, nor procedural freedom. ${ }^{\text {bo }}$

The uncertain legality of a practice on which most of the liner shipping industry had relied for so many years, plus the many cogent arguments in favor of the necessity of some sort of tying arrangement to prevent rate instability inimical to the commerce of the United States ${ }^{57}$ and to its subsidized carriers, prompted Congress to permit for two years (until June 30 , 1960) the continuation of dual-rate contracts in use and approved by the FMB, unless the Board cancels or modifies such agreements. ${ }^{68}$ This legislation will permit further study of the dual-rate contract system and allow the Congress to clarify its intentions concerning it. The litigations pursued by the Isbrandtsen Company have already brought to public attention several aspects of the system which warrant careful scrutiny. If the system is to be legalized explicitly, as the writer believes it should, Congress ought to instruct the responsible regulatory agency to supervise such matters as the reasonableness of the differential and other terms of the contract, in order to assure that a reasonable quid is offered for a reasonable quo.

One of the more perplexing problems requiring supervision is that of liquidated damages; and it is possible that they should be made illegal. Some conferences operate the dual-rate system without any provision for damages to be paid them by shippers who violate the contract to patronize conference members exclusively; but other conferences contend that without such a provision, they do not have adequate assurance of the shipper's loyalty and good faith. The Japan-Atlantic and Gulf Freight Conference contract, for example, provides that the shipper shall pay as liquidated damages fifty per cent of the amount of freight which the shipper would have paid had such shipment been made on a conference vessel. Until payment of these damages, the shipper is denied the reduced rate; and if he violates the agreement more than once in twelve months, he suffers cancellation of the agreement and the denial of another until all such damages have been paid. ${ }^{50}$ The majority of the Court in the Isbrandtsen case observed that ${ }^{60}$

the liquidated-damages provision bears a strong resemblance to the feature which Congress particularly objected to in the outlawed deferred-rebate system. Certainly the

\footnotetext{
${ }^{\text {to }}$ Senator Magnuson wrote: "This was a staggering blow to operations in this ficld, upsctting alike to vessel operators and to a great proportion of exporters." Magnuson, Maritime Legislative Problems Facing the 86th Congress, I 8 FED. B. J. 350, 352 (1958).

Es FMB v. Isbrandtsen Co., 356 U.S. 481 , 500, 519 et seq. (I958).

${ }^{87}$ Rate stability facilitates long-term business plans and forward trading. Furthermore, the exclusivepatronage contract system treats large and small shippers alike, whereas preferential rates are apt to be accorded large shippers when rates are open.

${ }^{\text {t8 }} 72$ Stat. 574 (1958), 46 U.S.C.A. \$812 (Supp. 1958).

${ }^{50}$ FMB v. Isbrandtsen Co., 356 U.S. $481,494-95$ (1958).

${ }^{\circ 0}$ Id. at 495 .
} 
coercive force of having to pay so large a sum of liquidated damages ties the shipper to the Conference almost as firmly as the prospect of losing the rebate.

Since provisions for such damages can be as onerous as the illegal deferred-rebate system, they should be carefully regulated if it is found necessary to allow their use. A procedure that would require shippers who have broken their contracts by patronizing an independent carrier to pay conference carriers the higher noncontract rate for a specified period of time, or on a specified tonnage, or on a specified percentage of specified shipments carried by conference members during some agreed future period would seem preferable. But such provisions should also be carefully supervised by the regulatory agency.

Tying procedures, while common in the ocean liner industry, are not unknown elsewhere ${ }^{61}$ and have recently been proposed for other modes of United States transport. Hence, an adequate solution of this problem for shipping may have precedential value for other segments of the industry. An officer of the International Air Transport Association (IATA) has recommended the employment of exclusivepatronage contracts for international air cargo. ${ }^{62}$ And recently, American railroads have proposed an offer of lower rates in return for a specified percentage of shipper's freight, in an attempt to regain high-rated traffic that has been lost to other modes of transport, especially motor carriers. ${ }^{63}$

Such "agreed rates," as they are called by railroads in Canada and the United Kingdom, differ from the exclusive-patronage system in that they do not necessarily require Ioo per cent loyalty and in that they are designed to meet competition from another mode of transport rather than to eliminate intraindustry competition. It is claimed that agreed charges would, by assuring the railroads of a specified percentage of the available traffic of signers, promise a more stable flow of traffic. Without such an agreement, it is pointed out, a rate reduction may not produce more business for the railroads, since their competitors might also reduce rates and leave the rails with a lower freight tariff but with little, if any, additional traffic. The percentage arrangement, it is urged, avoids discrimination against the small shipper, whereas lower rates based on a specified volume might not. In Canada, agreed charges are negotiated through the Canadian Freight Association; and in the United States, they would presumably be worked out through the rate bureaus, so that shippers could use any rail carrier serving the area and interrail competition would be unaffected. Such a percentage arrangement might be a solution ocean conferences could employ in lieu of liquidated damages.

Once again, it becomes clear that arrangements of this kind should be scrutinized carefully by the appropriate regulatory agency, and, if found constructive and permitted, their terms must be scrupulously supervised. The circumstantial approach,

${ }^{0}$ E.g., a loyalty discount of $2 \%$ was recently employed by the Aluminium Company of Canada on sales in the United Kingdom. The Economist, Oct. II, I958, p. 174. See also Turner, The Validity of Tying Arrangements Under the Antitrust Laws, 72 HARv. L. Rev. 50 (1958); Lewis, Notes on the Economics of Loyalty, 9 Econouica 333 (1942).

'Shechan, supra note 50 .

${ }^{\circ 3}$ Railway Age, Nov. 3, 1958, pp. 9-10. 
as opposed to a doctrinaire program, permits flexibility and experimentation and minimizes the risks of economic chaos.

If exemptions are to be made from the antitrust laws, however, the regulatory agencies must demonstrate greater independence and be more aggressive in demanding the maximum competition consistent with the economic characteristics of the regulated industry. ${ }^{84}$ A declaration by Congress that competitive principles should be maintained to the maximum extent practicable might be a useful addition to the relevant regulatory acts. ${ }^{6 \overline{5}}$

The problem of a regulatory agency's identification with the regulated industry would probably not be entirely solved, and this suggests that provision should also be made for the Department of Justice to take action when a regulatory agency appears indifferent to the competitive requirements of the congressional declaration..$^{00}$ This will contribute a regrettable element of uncertainty and violates a strict interpretation of the doctrine of "primary jurisdiction." It is fervently hoped that greater initiative on the part of the regulatory agencies will reduce the need for this departure from the "doctrine" and will minimize the danger that their activities will become, as the minority of the United States Supreme Court eloquently warns, "this carnival of procedural emptiness," and that greater regulatory zeal will also minimize the probabilities that litigants will be forced to undergo unnecessary expense and delay in shuttling back and forth between regulatory bodies and the courts. ${ }^{07} \mathrm{~A}$ system of checks and balances has been found useful in helping to reconcile political freedom and responsibility, however, even if it has, at times, been confusing and frustrating. A comparable system may be needed to reconcile the freedom of exemption from the antitrust laws with the economic responsibilities of regulated industries and their regulatory agencies to furnish satisfactory transportation services at rate levels close to the cost of providing them.

ot Several reforms might improve the performance of the regulatory agencies. The writer urges: (1) a clear and complete separation of regulatory from promotional functions: (2) reorganization of the regulatory agencies to emphasize their judicial character and appointment of members of judicial temperament and calibre; and (3) placing the agencies' appropriations in an omnibus bill with other funds for the judiciary, so as to insulate them from attack by lobbyists for the regulated industries.

${ }^{\circ 5}$ See Antitrust Subcomm. of the House Comm. on the Judiciary, stipra note 6, at 106, 267.

${ }^{\circ}$ A recent study of the insurance industry came to a similar conclusion. Dirlam \& Stelzer, The Insurance Industry: A Case Study in the Workability of Regulated Competition, 107 U. PA. L. REv. I99 (I958). It should be noted, however, that for freight transportation, the regulatory agency will often be involved in adjudicating between two oligopolies, and, consequently, there is no certainty that lower transport charges will be passed on to the consuming public. Action by the Department of Justice may be a necessary condition to assure an approach to the competitive solution, but if restricted to transportation, it is not a sufficient condition to protect the ultimate consumer.

${ }^{67}$ FMB v. Isbrandtsen Co., 356 U.S. 481,518 (1958). 